\title{
In Memoriam: Julius (Jules) August Kieser (20 December 1950 - 10 June 2014)
}

Jules Kieser was born in Pretoria, South Africa, in 1950. Jules' parents moved to Johannesburg where he enrolled at the University of the Witwatersrand. He obtained a BSc in Anatomy in 1971, followed by a Bachelor of Dental Sciences in 1975. Jules then practiced dentistry in the outback of South Africa, London and Johannesburg, with his wife Glynny working as his assistant. In 1989, Jules received his PhD from the University of the Witwatersrand, working under Phillip Tobias on the dentition of the Lengua Indians of Paraguay. After holding positions of consultant and honorary lecturer, Jules was appointed as Professor and Reader of Craniofacial Biology at the University of the Witwatersrand in 1991. In 1996, Jules and his family emigrated from South Africa to New Zealand, where he was appointed Chair in Oral Biology and Professor in the Department of Oral Sciences and Orthodontics at the University of Otago. In 2001 he was awarded his DSc from the University of the Witwatersrand.

In Otago, Jules held positions as Chair and Professor at the Department of Oral Sciences and Orthodontics, and Associate Dean for Research in the Division of Health Sciences. He was the inaugural Director of the Sir John Walsh Research Institute and Associate Dean for Research at the Faculty of Dentistry. Since his arrival in New Zealand in 1996, he lectured Oral Biology, Biomedical Sciences and Forensic Biology to many dental surgery, oral health and forensic science students. He was regarded widely as a positive and enthusiastic lecturer, with a relaxed, humorous and engaging style of teaching.

Jules had a prolific research record, having published 196 journal articles and four books. His research interests were broad and spanned across diverse disciplines such as dental anthropology, craniofacial biology and biomechanics, forensic biology and dental education. In particular, Jules' contributions to the fields of human odontometrics, dental asymmetry and development instability, and many other areas of craniofacial biology were valued by dental anthropologists worldwide. Jules studied the dentition of modern human populations, of early archaeological and fossil human remains, and of diverse animals such as crocodiles, primates, tuataras and dolphins.

He was instrumental in the development of forensic biology research in New Zealand and his practical expertise in forensic odontology was fundamental in the identification of the victims of the 2004 Thai Tsunami and 2011 Christchurch Earthquake in New Zealand. He received a New Zealand Special Services Medal for his service during the Thai Tsunami and a New Zealand Commissioner of Police Citation for his work in Christchurch. Other awards included Fellowships of the Galton Institute of London (1994) and Linnean Society of London (1995), an Ad Hominem Fellowship in Dental Surgery from the Royal College of Surgeons of Edinburgh (2004), the Alan Docking Award for Distinguished Research in Dentistry (2008), a Fellowship of the Faculty of Maxillofacial Pathology of the Royal College of Pathologists of Australasia (2013), a Fellowship of the Chartered Society of Forensic Sciences (2014), and a Wits Distinguished Scholar and a Wits-Carnegie Alumni Diaspora Fellowship (2014).

Jules was a keen and experienced scuba diver and had diving as one of his main hobbies. He held a 3rd Dan Karate black belt and had been a keen martial artist. Jules was also an eager rugby enthusiast. He enjoyed gardening, taking his dogs for bush walks and observing and attracting native birds to his property, especially New Zealand wood pigeons. Jules had a substantial library, including many diverse subjects outside his work interests. He was particularly interested in world history, war and strategy, and the evolution and development of civilizations. He enjoyed trying different varieties of chocolate and wine from other parts of the world during his multiple travels overseas. Jules and Glynny had four children: Annie, JJ, Daniel and David, who, from very early days, had always been involved in his work and research. As a result, many of his students and colleagues were also friends of his family. 
Jules will be remembered as a very supportive and influential mentor and outstanding role model. His warm and positive personality was combined with a sharp mind and generous heart. Jules always fostered collaboration instead of competition; and always saw the development and advancement of the careers of his students and peers as beneficial to his own career development. He was a very humble and humane person, and a skilled master of social interactions. His contributions and his influence on his colleagues went way beyond the scientific and academic environments. We will miss this exceptional friend and colleague greatly and he will be always remembered as an example of someone we should all strive to emulate.

\section{Carolina Loch ${ }^{1}$, Grant Townsend ${ }^{2}$ and Christopher Dean ${ }^{3}$}

${ }^{1}$ Sir John Walsh Research Institute, Faculty of Dentistry, University of Otago, New Zealand

${ }^{2}$ School of Dentistry, University of Adelaide, South Australia

${ }^{3}$ Cell and Developmental Biology, University College London, UK

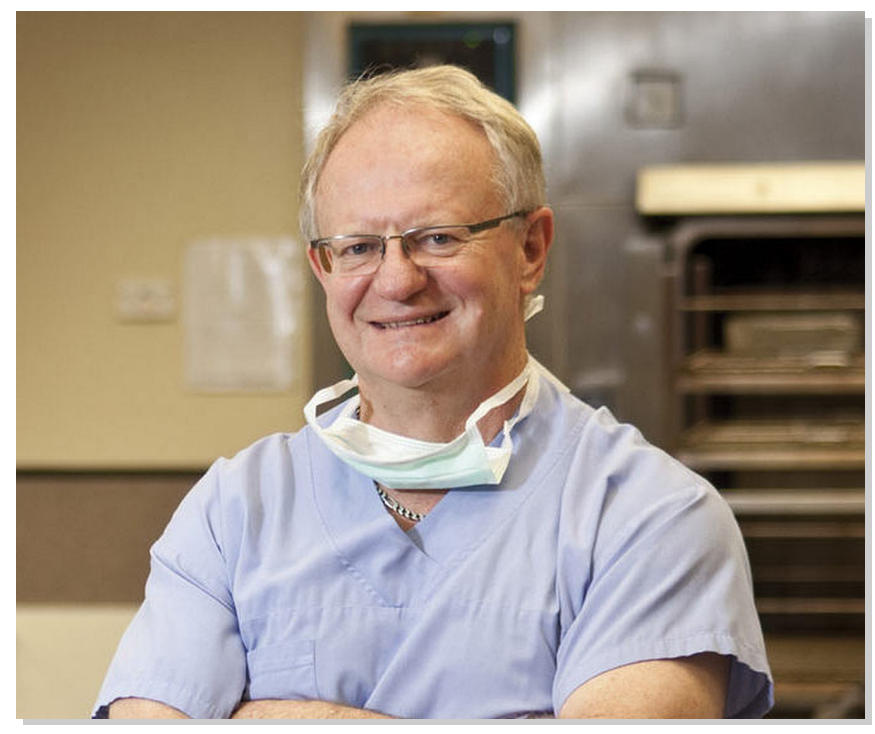

